\title{
ОСОБЕННОСТИ СИСТЕМЫ МЕСТНОГО САМОУПРАВЛЕНИЯ ГУБЕРНИИ КАЗАНСКОГО УЧЕБНОГО ОКРУГА ХІХ В.
}

\section{FEATURES OF THE LOCAL SELF-GOVERNMENT SYSTEM OF THE KAZAN EDUCATIONAL DISTRICT OF THE XIX CENTURY}

\section{Cherkashina}

Summary: This article analyzes the features of the management system in the Kazan educational district. The list of official duties of the administrative staff of the district is analyzed, the changes that took place in the Kazan educational district in the 19th century are considered.

Keywords: local government, Kazan educational district, province, administrative activities, educational institution.

\author{
Черкашина Вера Витальевна \\ Аспирант, Казанский (Приволжский) \\ федеральный университет \\ homyak_09@mail.ru
}

Аннотация: В данной статье анализируются особенности системы управления в Казанском учебном округе. Анализируются перечень должностных обязанностей управленческого состава округа, рассматриваются изменения, происходившие в Казанском учебном округе в XIX веке.

Ключевые слова: местное самоуправление, Казанский учебный округ, губерния, административная деятельность, учебное учреждение.
$\mathrm{P}$ еформаторской деятельности в отношении местного самоуправления в Казанской губернии XIX века была обусловлена необходимыми изменения, прежде всего, заключающейся в форме управления. В начале своей деятельности земства и городские учреждения самоуправления руководствовались реализовать свое самоуправление в рамках формы государственного правления, что выразилось в создании адаптированной для местного общества форму самоуправления. Однако ввиду неоднородного состава населения Казанской губернии, включая множество национальностей и конфессий, местная система управления должна была учитывать эти факты. местные органы самоуправления должны были прислушиваться к интересам разных народностей и учитывать их при осуществлении властных полномочий. Таким образом, местное самоуправление Казанской губернии необходимо охарактеризовать как руководствующее в своей деятельности принципом всесословности, а также принимающее участие в решении вопросов местного значения всех сословных групп [8].

Прежде чем обратиться к анализу местного самоуправления Казанского учебного округа, необходимо проанализировать исторические предпосылки его создания. Так, ими послужило принятия указа императора Александра I в январе 1803 года «Об учреждении учебных округов, с назначением для каждого особых губерний». В нем на нормативно-правовом уровне закреплялись новые основы российской образовательной системы. Указом было закреплено, что лицо не сможет занять пост гражданской должности, если не получит образование в университете. Таким образом, можно от- метить, что реформа Александра I способствовала массовому получению образования среди населения России, если они хотели занять чин гражданской службы.

Данный указ также закреплял состав ступеней образования, согласно которому можно выделить три ступени, от низшей к высшей [3]:

1. Одноклассное приходское училище - пришло на смену народным училищам;

2. Уездное трехклассное училище - училище, которое должно было быть в каждом городе России;

3. Шестиклассная гимназия в губернском городе.

Деятельность Казанского учебного округа берет свое начало в рамках данного указа. Им утверждалось, что Россия должна быть разделена на шесть учебных округов, главным центром которых выступают университеты. Управлять же данными округами должны были попечители, которых император самостоятельно назначал на данную должность [4]. Стоит отметить, что должность попечителя не отличалась объемным перечнем задач. В них входили лишь некоторые надзорные и контрольных функции за деятельностью учебных заведений, входящих в управляемый попечителем округ. Фактически же контроль над учебным процессом в округах осуществляли университеты, в обязанность которых входило:

- разработка планов учебной деятельности;

- печать учебников по различным дисциплинам;

- осуществление контрольных функций в отношении гимназии округа и т.д.

В сферу ведения директора гимназии входил кон- 
троль над уездными училищами губернии, а за деятельность приходских училищ уезда отвечал смотритель.

Система образования России в начале XIX века контролировалась единым органом - Главным управлением училищ, который являлся коллегиальным по своей структуре. В данный орган входили министры народного просвещения и другие лица, которые избирались императором. В число основных задач Главного управления училищ входило:

- разработка учебных планов образовательных заведений, созданных по указу Александра I, их анализ и внедрение в учебную деятельность;

- составление пояснений, исправлений документов, закрепляющих деятельность учебного процесса, отмена локальных актов в данной области;

- рассмотрение и разрешение различных вопросов, возникающих в ходе учебной деятельности;

- рассмотрение кандидатур, выдвигаемых на должность педагогов, вопросы их назначение, перемещения, снятия с должности;

- обеспечение училищ учебными материалами книгами, пособиями и т.д.;

- управление хозяйственной деятельностью учебных заведений;

- анализ имущественных вопросов и их решение;

- составление отчетности согласно анализу деятельности учебных учреждений и др.

Казанский учебный округ был основан 24 января 1802 года. Его центральным органом был Казанский университет, который появился в 1804 году. Необходимо сказать несколько слов об истории данного университета. Так, после учреждения Министерство народного просвещения и издания предварительных правил народного образования, в ноябре 1804 года российский император утвердил первый общий Университетский устав, уставы Московского, Харьковского и Казанского университетов, а также уставы учебных заведений, находящихся в ведении университетов [6].

Долгое время Казанский университет был самым восточным высшим учебным заведением России. Образовательный округ, возглавляемый Казанским университетом, включал Поволжье, Пензенскую и Тамбовскую губернии, Прикамье и Урал, Сибирь и Кавказ. В первые десятилетия своего существования университет стал крупным центром образования и науки. Здесь сформировался ряд научных направлений и школ: математическая, химическая, медицинская, лингвистическая, геологическая, геоботаническая и др.

Согласно Уставу 1804 года, университет должен был открыть 28 кафедр в рамках четырех следующих факультетов: нравственных и политических наук; физики и ма- тематики; медицины; филологии, включая кафедру восточных языков.

Первоначально университет занимал часть помещений первой императорской классической школы. Но вскоре пришлось реконструировать существующие учебные заведения и строить новые. В 1822-1842 годах был построен университетский комплекс: главный корпус, обсерватория, анатомический театр, библиотека, химическая лаборатория, включая физический кабинет, клиника, здания вспомогательных служб. Руководил работами Н.И. Лобачевский, который в 1827-1846 годах был ректором университета.

В 1835 году был введен Университетский устав императора Николая I Об учреждении трех кафедр: философской (филологической и физико-математической), юридической и медицинской. В 1863 году, после введения Университетского Устава Александра II, они были реорганизованы в четыре факультета: историко-филологический, физико-математический, юридический и медицинский.

С 1834 года университет начал выпускать академические записки. Большую роль в развитии наук сыграли и различные научные общества, образовавшиеся при Казанском университете: в 1839 году было создано Казанское экономическое общество; в 1878 году - Общество археологии, истории и этнографии. В 1875-1883 годах в университете была создана Казанская лингвистическая школа. В 1892 году по инициативе В. М. Бехтерева было организовано неврологическое общество. В Казанском университете работали выдающиеся ученые, сделавшие важные научные открытия и основавшие различные научные школы. Среди них: А.М. Бутлеров, А.В. Вишневский, Е.К. Завойский, Н.Н. Зинин, К.Е. Клаус, Н.И. Лобачевский, В.А. Энгельгардт и многие другие.

Говоря об административно-территориальном устройстве Казанского учебного округа, необходимо выделить его единицы. Всего в него входило шесть губерний: Вятская, Казанская, Самарская, Саратовская, Симбирская, Астразанская. Кроме того, в учебный округ входили также территории Сибири и Средней Азии, которые, однако, позднее станут относится к Сибирскому учебному округу.

Важно отметить, что Казанский учебный округ в сравнении с другими учебными округами отличался своей большой территорией. Данный факт создавал некоторые проблемы в управлении округом, поскольку отягчало своевременное функционирование различных внутренних ведомств ввиду их нахождения в разных округах. Гигантская бюрократическая машина была медлительной и неповоротливой. Поэтому требовалось выделение не- 
скольких учебных округов из состава Казанского.

Далее обратимся к анализу системы управления Казанского учебного округа. Они были представлены [7]:

- Управлением округа;

- Канцелярией попечителя;

- дирекцией народных училищ;

- администрацией учебного заведения.

Во второй половине XIX века структура управления включала в себя структурные компоненты, на которых мы остановимся подробнее. Так, глава учебного округа (попечитель) - являлся представителем министерства в своем регионе. За почти век своего существования, Казанский учебный округ сменил множество попечителей. Первым попечителем Казанского учебного округа был назначен С.А. Румовский, ученый и педагог XIX века. В разное время попечителями Казанского учебного округа были такие выдающиеся личности как М.А. Салтыков, П.П. Вяземский, М.Н. Мусин-Пушкин, Н.И. Лобачевский, В.А. Попов, Э.А. Грубер, П.Д. Шестаков А.Н. Деревицкий, М.М. Алексеенко и др. [10].

Попечителю были подотчетны служащие Управления и Канцелярии, дирекций народных училищ, а также само начальство учебных заведений Казанского учебного округа. В должностные обязанности попечителя входило определение должностных обязанностей для служащих того или иного направления учебной деятельности, назначение, повышение, отстранение и увольнение служащих со службы, а также прочая «кадровая» работа - назначение отпусков, представление к награде и т.д. важно подчеркнуть, что в некоторых исключительных случаях (назначение на особые должности и увольнение с них) попечитель должен был получать разрешение министра просвещения [6]. Попечителю назначался помощник попечителя, который являлся исполняющим обязанности в отсутствие попечителя.

Попечитель выбирался из числа членов Главного правления училищ, представлявшего собой совет Министерства народного просвещения [6]. Стоит отметить, что в начале XIX века преимущественно заседали в Петербурге, а органом оперативного управления округом, в свою очередь, являлся училищный комитет - орган, состоящий из шести профессоров под председательством ректора университета. Губернские города Казанского учебного округа имели в своем составе губернское училище или гимназию. Данные учебные учреждения также входили в предмет ведения училищного комитета.

Согласно Положению об учебных округах от 25 июня 1835 года, народные училища, наравне с гимназиями, были изъяты из ведомства университетов. Данным Положением также была утверждена должность помощни- ка учредителя, которая появилась в Казанском учебном округе только в 40x годах XIX века. Данное Положение дает нам представление о том, что с начала учреждении учебных округов была пересмотрена административная система управления ими, поскольку деятельность попечителя частично была передана его помощнику, таким образом подчеркнув необходимость разделения должностных полномочий.

В 1835 году управление высшей школой и народным образованием было разделено. Так, учебные округа из ведения университетов были изъяты и переданы в ведение Министерства Народного Просвещения. Это означало, что должностные обязанности попечителей были изменены и теперь на них возлагалась ответственность за обеспечение образовательной деятельности в округе, а не на уровне управления университетом. С этого момента добавляются новые органы и должности - попечительские советы и окружные инспекторы, а также внедрялись дирекции народных училищ, губернские и уездные училищные советы.

В деятельность окружных инспекций входили исполнительные функции. В Казанском учебном округе было утверждено два окружных инспектора (а в ходе реформ 1867 года был добавлен и третий инспектор), обязанности которых были разделены попечителем. В ходе своих должностных обязанностей, окружные инспекторы осуществляли [1]:

- ревизии учебных заведений;

- инспекторские проверки в рамках посещений учебных заведений;

- регистрирование всех нарушений, обнаруженных в ходе посещения учреждений;

- знакомство педагогического состава учебных учреждений с методиками образовательного процесса;

- применение мер административного характера в отношении педагогов, нарушающих установленные правила и регламенты работы в учебных учреждениях;

- поддержку методической деятельности педагогическому составу учебных учреждений;

- делопроизводство Управления Казанским учебным округом.

B 70x годах XIX века Министерством просвещения был изменен регламент деятельности окружных инспекторов, согласно которому они занимали в своей деятельности в определенных типах учебных заведений. Таким образом, был распределен предмет управления - одни инспекторы управляли только гимназиями, другие училищами [7]. Подобное распределение способствовало установлению функциональных обязанностей между работниками, а также определению ревизионных визи- 
тов учебных учреждений Казанского учебного округа. Данный принцип распределения наложил свой отпечаток на инородческих школах, в частности, один окружной инспектор курировал чувашские школы [7].

В 1835 году в Казанском учебном округе был создан Попечительский совет - коллегиальный орган, целью которого являлось ведение административных вопросов организации учебного процесса в округе. В совет входили помощник попечителя, окружные инспекторы, дирекция учебных заведений и т.д.

В рамках своей деятельности, Попечительский совет выполнял следующие функции [5]:

- вынесение постановлений;

- осуществление контроля над руководством учебных учреждений;

- обсуждение отчетности;

- решение вопросов, вынесенных на обсуждение попечителем;

- оказание поддержки в решении проблем хозяйственного характера и др.

Важным органом являлась Канцелярия попечителя Казанского учебного округа. В ее полномочия входили сбор информации о положении дел в учебной деятельности округа.

Масштабная территория Казанского учебного округа внесла в коррективы обязанностей окружных инспекторов, поскольку в нем находилось большое количество учебных учреждений, которые расширялись, появлялись новые учреждения. В этой связи, делопроизводственная деятельность инспекторов увеличилась, поскольку их необходимо было обрабатывать информацию, поступавшую из всех учебных учреждений Казанского учебного округа. Ввиду изменений объема деятельности, чтобы успешно выполнять свою работу, на законодательном уровне Департаментом просвещения были созданы инструкции для окружных инспекторов, включающие в себя различные регламенты, постановления, распоряжения, которые они должны были знать.

Директоры гимназии были одновременно директорами уездных училищ, которых должно было быть, по крайней мере, по одному в каждом уездном и губернском городе. Смотрители уездных училищ отвечали за состояние дел в приходских учебных заведениях.

Стоит отметить, что к педагогическому составу образовательных учреждений Казанского учебного округа предъявлялись серьезные требования; так, например, для подготовки педагогов гимназий были основаны педагогические институты [9]. В 1805 году в Казани педа- гогический институт была преобразована гимназия - из этого института в 1815 году были образованы Казанский университет и Первая Казанская мужская гимназия.

За время своего существования Казанский учебный округ неоднократно подвергался изменениям. Так, например, в 1824 году школы Кавказа и Астраханской губернии перешли в ведение Харьковского учебного округа. Через несколько лет, в 1833 году Астраханская губерния была вновь введена в состав Казанского учебного округа.

Важно отметить, что в Казанском учебном округе в одном из первых было обращено внимание на внедрение образовательных программ для женщин, обусловленные социокультурными аспектами Российского движения за право получения высшего образования и педагогической профессии. Так, во второй половине XIX века российские женщины в борьбе за равенство с мужчинами потребовали равных прав в области образования, чтобы получить возможность расширить свою профессиональную деятельность и, следовательно, использовать свои способности на благо общества и достичь экономической независимости. В этой связи в 1874 году группа профессоров Казанского университета, получив одобрение на расширение цикла естественноисторических и математических курсов, представила в университетский совет проект учреждения Высших женских учебных курсов при Казанском Императорском Университете ввиду необходимости женского высшего образования, ощущаемой многими, а также заявляемой с разных сторон, что само правительство одобряет данную инициативу [2]. И Университетский совет, и попечитель Казанского учебного округа отнеслись к предложению профессоров благосклонно и направили в Министерство образования просьбу об открытии женских курсов вместе с проектом и программой. Высшие женские курсы были открыты в Казани 3 октября 1876 года как двухлетний эксперимент по образцу уже существовавших Высших курсов профессора В.И. Герье в Москве. Таким образом, образовательная деятельность Казанского учебного округа поспособствовала развитию получения образования среди женщин.

В завершении хотелось бы сделать ряд выводов. В начале царствования императора Александра I в ходе реформ, касающихся образования, были разработаны новые принципы организации народного образования и новые типы учебных заведений, в рамках которых и был основан Казанский учебный округ. Как самостоятельная административная единица, Казанский учебный округ просуществовал практически век - до февраля 1918 года. 


\section{ЛИТЕРАТУРА}

1. Агафонов Н.Я. К 100-летию учреждения учебных округов (Краткий исторический очерк Казанского Учебного округа, читанный в день юбилея, 24 января 1903 г.). Казань, 1903. 192 с.

2. Деревицкий А.Н. Женское образование в России и за границей. Исторические справки и практические указания. Одесса, 1902. 45 с.

3. Из жизни Казанского учебного округа // Вестник образования и воспитания. 1914. № 2. 16 с.

4. Магсумов Т.А., Корнилова И.В. Циркуляры попечителей учебных округов как исторический источник // Международный журнал экспериментального образования. 2011. № 11.117 с.

5. Национальный архив Республики Тататрстан (НА РТ). Ф. 92. Оп. 1. Д. 24737. Л. 143.

6. Перечень дел, решение которых предоставляется попечителям КУО. Казань, 1915. 286 с.

7. Положение об Учебных округах МНП // Сборник постановлений по Министерству народного просвещения. М., 1875. Т. 2. С. 955-957.

8. Рождественский Б.П. Революционное движение учащихся средних школ в революции 1905-1907 гг. в Казанском учебном округе: Дисс. ... канд. пед. наук. Казань, 1941. 421 с.

9. Спешков С.Ф. Краткие дидактические указания для готовившихся к преподавательской деятельности / сост. бывшим членом испытательного комитета при Управлении Рижского учебного округа Спешковым. Рига, 1907. 160 с.

10. Шилов Д.Н. Государственные деятели Российской империи. 1802-1917 гг.: библиографический справочник. СПб., 2001. 936 с.

о Черкашина Вера Витальевна (homyak_09@mail.ru).

Журнал «Современная наука: актуальные проблемы теории и практики»

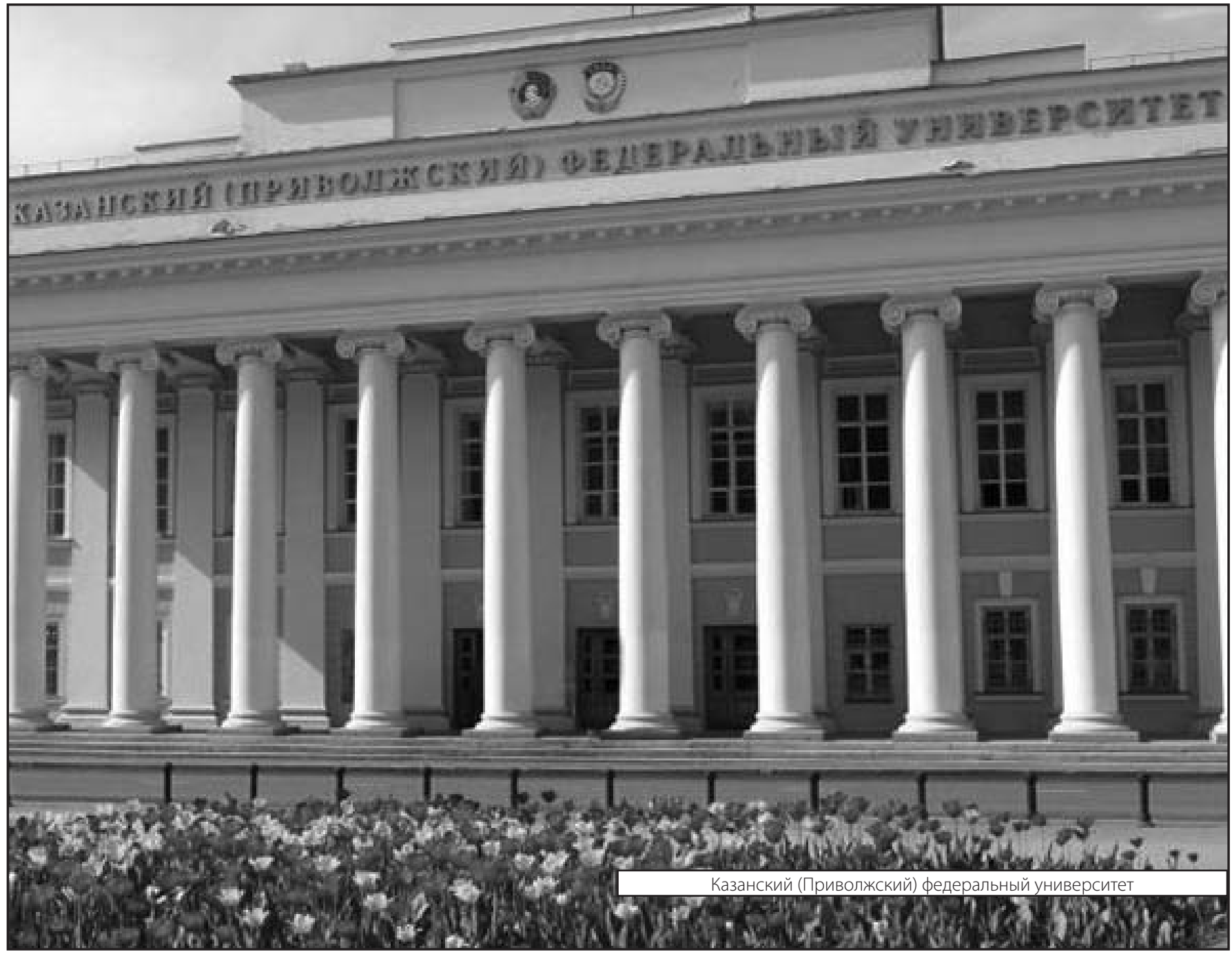

